\title{
ЛАТИНОМОВНА СПАДЩИНА УКРАЇНИ ЯК ЕТАЛОН У ФІЛОСОФІЇ СЕРЦЯ ГРИГОРІЯ СКОВОРОДИ: СИМВОЛІКА ЕМБЛЕМАТИЧНОЇ ПОЕЗІЇ ТЕОФАНА ПРОКОПОВИЧА
}

\section{Свередюк У. Д.}

\section{ВСТУП}

Принцип точності в науці, як відповідність опису звірки з еталоном, грунтується на довірі в описі як до звізуалізованого зображення, так і до візуалізуючого слова. У цьому полягає універсальний принцип причинно-наслідкових зв'язків, який у гуманітарному вимірі означає також зв'язок між матір'ю та дитиною. Християнство вивело закон світла в антропоцентричній системі як зв'язок між Пречистою Дівою Марією з малим Ісусом на руках у вигляді образа, зображеного на площині, впізнаваного при одному погляді кожним християнином. Це допомагає віруючій людині зберігати людську гідність і не опускатися до тваринних інстинктів у випадках побудови перспективи в «неситому оці», оскільки будь-яка перспектива в житті неможлива без існування зв'язку між причиною і наслідком, за аналогією зв'язку між матір'ю і дитиною, незалежно від того, звідки до нього підходити: з боку матері, чи з боку дитини. Тільки у вільному суспільстві людина вибирає за потребою серця в конкретних умовах часу i простору необхідну точку відліку, де звізуалізована форма набуває вигляду: ідеї, ємності або краси. Натомість кожне невільне суспільство, нав'язуючи свою фіксацію, зумисне ігнорує і навіть повністю нівелює всі інші, що $\epsilon$ втручанням у закони гармонії. Серце із плинною кров'ю, що кровопостачає всі органи людського організму включно з оком і самим серцем, забезпечує стан біологічної рівноваги (кордоцентризм) за будьяких обставин на засадах добропрекрасного (калокагатії) в гуманітарному вимірі, де серце $є$ мірою кількості доброти, а око якості прекрасного.

Сьогодні можемо сповістити про знахідку першої згадки в українській літературній традиції, а саме в латиномовній літературі Теофана Прокоповича - зв'язку між матір'ю і дитиною, яка подана як міра кордоцентризму і точка відліку в гуманітарному масштабуванні людського буття. $\mathcal{C}$ всі підстави розглядати його як ігнорований у радянські часи, офтальмологічний мірний термін minimum visibile 
(найменше зриме, величина образу-символа, яка починає розрізнятися та виокремлюватися на образі-картині як одиниця виміру (точка відліку) зображення на рівномірному білому фоні) у системі симетричних просторовочасових пропорцій, або співвідношень цілого материнського кола-хвилі (побаченого зором) з цілим дочірнім коломхвилею (іменованого озвученим словом) як символізм у системі, де повня не може бути повнішою, вагітність більшою чи меншою, а отже, цілісна людина постає (вважається і рахується) незалежною та неподільною. Тож науковці Львівського університету, що названий іменем філософа Івана Франка, на підставі наукових підходів, висвітлених у його творі «Лис Микита», пропонують повернутися до антропоцентричних і кордоцентричних мірок у гуманістиці, базованих на мірах ока, відомих 3 античних часів та використовуваних у класичній літературі передусім як мірна термінологія в латиномовній спадщині України. Філософія співмірності (еметропії, очевидності) завжди перемагає ілюзію неситого ока, як Лис Микита, в імені якого закладена перемога (Нікіта, Ніка - богиня перемоги), у фінальному двобої остаточно перемагає Вовка Неситого (вічно несите око як однозначність міри неситого шлунка). Отож, ідеться про двійкову систему мір у цілочисельній математиці Піфагора, яка не може мати характеристики величини міри, бути більше чи менше вираженою, оскільки слово-символ позначає присутність або відсутність значення як цілого і неподільного стану речей, а отже, як мірну одиницю найменшого зримого: воля-неволя, залежність-незалежність, ситістьнеситість. Такий підхід здавна мав фундаментальне значення в антропоцентричному вимірі, оскільки людина може бути винятково тільки в одному 3 двох станів: вільна-невільна, залежна-незалежна, сита-несита, вірна-невірна, що автоматично виключає усяке міркування частинами цілого.

\section{1. Засади мірної системи української філософії кордоцентризму Григорія Сковороди в дослідженнях львівських науковців}

У монографії львівського неолатиніста Мирослава Трофимука «Латиномовна література України XV - XIX ст.: жанри, мотиви, ідеї» грунтовно проаналізовано зразки епіграм авторства самого Теофана Прокоповича (1681-1736). Досліджуючи схеми побудови перспектив, у цих зразках можна виокремити приведення до співмірності (еметропії, очевидності), яка також відома в мистецтві як ілюзія «стежачого ока». Як зауважив автор, епіграми на релігійні теми $є$ зразками емблематичної поезії: «Очевидно йдеться про іконографічні зображення, враження від огляду котрих і стали поштовхом до написання цих творів. На такий висновок наштовхують і їхні назви, які 
містять фразу “In imaginem...”: На зображення (прийменник in може мати й негативну, заперечну конотацію... “проти”)...»". Це свідчить про те, що ми маємо справу не стільки 3 мовними символами як із візуальними, точніше 3 поєднанням одних i других за законами побудови зображення в оці-сфері, що створює особливий ефект дії на читача, відомий як Живе Слово, яке утворюється за програмою поєднання стереотипного і стереоскопічного бачення з підсвідомим розумінням символіки у сферах. Прийменник in в одному разі передбачатиме отримання імпульсу сили в колі того, хто наштовхується, а в іншому - того, на кого наштовхуються. Обговорення гармонії у сферах було звичним для середньовіччя. I саме про це йдеться у дискусіях про відкритість класичної літератури: про механізми, які не дають зациклитися в межах окремих символів (симболів), а забезпечують природний для людини перехід на наступні кола простору і часу. У праці неодноразово подано вказівки на такі механізми: «Теофан Прокопович також використовує фонетичну та семантичну гру словами - улюблений засіб барокових авторів...»². Філологи, можливо, ще не повністю усвідомлюють, що так звана «гра слів» $\epsilon$ якраз отим механізмом програмування кордоцентризму i переходом з руху по колу на рух по спіралі: натрапивши на два слова, подібні за звучанням від питання який? (відмінності у сфері схожого звучання), читач автоматично переходить до питання чий? (відмінності сфер різного значення, 3 переходом до однієї з них). Так відбувається візуалізація фіксацій, що в українській мові відомі також як суфікс, префікс і закінчення.

Візуалізація як побудова прямої чи оберненої перспективи в просторі і часі завжди пов'язана зі символікою світла i, відповідно, побудовою зображення за законами оптики. Натомість в антропоцентричному вимірі символізм завжди пов'язаний не зі зображеннями як стереотипами часу і простору: словами-термінами $\mathrm{i}$ словами-емоціями, а зі світлом людських очей, де символізм розглядається 3 позицій симбіозу. Тільки у цьому разі слова-терміни завжди співмірні зі словами-емоціями оскільки емметропія і емпатія в системі кордоцентризму і сродності обов'язково приводить до понять Слова Живого та Всевидящого Ока, що в образотворчому мистецтві відповідає ілюзії стежачого ока. Академік Тарас Шевченко як художник, що професійно володів технікою побудови перспектив на площині паперу i як поет-білінгвал, означив одиницю виміру

1 Трофимук М. Латиномовна література України XV - IX ст.: жанри, мотиви, ідеї / Мирослав Трофимук. Львів : ЛНУ ім. Івана Франка, 2014. С. 180.

${ }^{2}$ Там само. С. 176. 
кордоцентризму словами: «Нічого кращого немає, / Як тая мати молодая / 3 своїм дитяточком малим» ${ }^{3}$. До цієї цитати за принципом, що ідеальне (пречисте) материнське коло-хвиля за законами просторочасу в хвильовій оптиці породжує таке ж ідеальне дочірнє коло-хвилю, звернувся і Мирослав Трофимук після аналізу поезії Теофана Прокоповича. Отже, сховатися від «стежачого ока» "In imaginem..." в часі за умови співмірності поглядів читача й автора справді неможливо. Основним питанням, що виникає спонтанно, $\epsilon$ збереження чи втрата цілісності як ідеальності форми кола, яка може стосуватися як людської гідності, так і людського життя, за умови, що людину розглядатимемо як замкнуту біологічну систему. У разі емпатійних взаємовідносин поділ стосуватиметься передачі знання, дум-дітей як міри міркуванням, а отже, лише у цьому разі цілісність не тільки зберігається, але й примножується для обох учасників відповідно до їхнього рівня об'єктивного і суб'єктивного розуміння символіки на момент реального часу за принципом фонтанів Сковороди: як маленький учень, так i старий викладач взаємозбагачуються, вибравши шлях емпатичного спілкування як ціле до цілого, на противагу симпатії або антипатії, де закон гармонії грунтується на співвідношенні взаємозалежних частин. Аналогічне співвідношення виникає в системі сім'ї як баланс досвіду дітей i батьків. Проте кровний зв'язок між матір'ю та дитиною завжди був еталоном в антропоцентричному вимірі через очевидність вагітності, пологів і найперше досвіду життя у сфері символіки материнської мови під час виховання порозуміння в сім’ї як у найближчому i найріднішому довкіллі. У цьому і полягає філософія кордоцентризму Григорія Сковороди на християнських засадах двох заповідей любові: до Бога і до ближнього.

Переходити від далекозорої (гіперметропічної) міри ока, властивої мисливцям, до співмірної (еметропічної) цілочисельної філософії Піфагора закликає ректор Франкового університету, доктор філософських наук, професор Володимир Мельник: «Зміна екологічної парадигми має трансформувати не просто перетворювальноспоживацьке ставлення людини до природи, а передусім надати цьому відношенню людиновимірного, духовно-морального масштабу» ${ }^{4}$. Якщо взяти до уваги, що око - це мозок на периферії, тоді класичну літературу можна розглядати під кутом нейролінгвістичного

3 Трофимук М. Латиномовна література України XV - IX ст.: жанри, мотиви, ідеї. Львів : ЛНУ ім. Івана Франка, 2014. С. 181-182.

4 Мельник В. Філософія і наука. Антологія сучасної філософії науки, або усмішка ASIMO. Львів : ЛНУ ім. Івана Франка, 2017. С. 15. 
програмування. Саме такий підхід започаткував класичний філолог, професор Андрій Содомора, досліджуючи проблеми неперекладності: «Шевченків садок і Франкове поле», «Студії одного вірша», «Афористичні етюди» та інше. Тільки 2017-го, у рік його вісімдесятиріччя вийшло друком аж 5 фундаментальних досліджень, які можна назвати схемами українського нейролінгвістичного програмування за законами класики. Звівши все до площини одної поезії (одного афоризму), він, наче лікар, досліджує кожне слово, кожен звук на вірність цілочисельним законам гармонії, наче співмірність як неперекладність роботи вірного людського серця на кардіограмі й ехограмі. Живе Слово, як і живе серце, повинно не тільки бути на своєму місці та гарно ритмічно звучати-стукати в грудях, але перш за все невтомно гарно і правильно працювати завжди: і тоді, коли людина змінює своєю працею зримий світ, і тоді, коли людський мозок бачить сюрреалістичні сни, абсолютно відірвані від об’єктивної реальності. Аналогічну методику застосовано і під час роботи 3 фольклорними текстами. Науковці кафедри української фольклористики імені академіка Філарета Колесси Львівського університету у своїх студіях просунулися чи не найдалі в дослідженні співмірності, застосовуючи міри ока. За класифікацією професора Івана Денисюка, засоби фольклорного стилю поділено на три типи образності: «1) постійні епітети, порівняння, метафори, усталені засоби поетичного синтаксису - так звані loci communes (загальні місця)»" ${ }^{5}$, які 3 позиції хвильової оптики підпорядковуються законам поля зору, відцентрових, розбіжних хвиль, будують просторово-часові співвідношення за аналогією близорукості (короткозорості) в оптометрії;

«2) рідкісні гіперметафоричні утворення...- loci raritates» ${ }^{6}$, що відповідають законам гіперметропічного (далекозорого) ока, або фізиці доцентрових, збіжних хвиль;

«3) слова і словосполучення, які виконують роль символів» ${ }^{7}$, що однозначно $\epsilon$ аналогією утворення зображень в еметропічному (співмірному) оці, за законами гармонічних коливань, кола, символізму. Як бачимо, тільки у третьому разі коло набуває значення символу чіткого зору, що поширюється на всі очі всіх живих істот в умовах життя на Землі: як людей, так і звірів (що пояснює феномен звірів у фольклорі). У такий спосіб професор Іван Денисюк створив науково обгрунтовану фізіологією зору підвалину для оновленого

5 Гарасим Я. Національна самобутність естетики українського пісенного фольклору. Львів : Львівський національний університет імені Івана Франка, 2010. C. 287.

6 Там само.

${ }^{7}$ Там само. 
трактування філософії кордоцентризму Григорія Сковороди, тобто три варіанти мовного програмування на підставі зв'язку серця 3 оком. Отже, стає зрозуміло, від яких пасток застерігав Іван Франко як філософ словами Лиса Микити, бо пов'язані вони 3 fovea centralis i macula lutea - центральною ямкою і жовтою плямою, анатомічними структурами ока людини, які, наче пастки, для людини, що вірить в ілюзії, а не голосові серця. Отже, основним завданням класичної філології був завжди пошук «золотої середини», «Живого Слова» у світі ілюзій, що безсумнівно пов'язано 3 цілочисельними законами виникнення чіткого зображення в оці і символікою «неситого ока», яке міряе тільки частинами.

Завдання цієї статті полягає у тому, щоб показати механізми, як символи філологів, художників, геометрів, теологів та істориків, об'єднані в одній поезії, утворюють еталон міри в гуманітаристиці. Це, у ширшому контексті, трактують як лінгвістичну технологію, що міститься в розумінні вислову «класична мова», «класична література». Вона грунтується на мірах ока, де критерієм чіткості зображення в плоскопаралельному вимірі (зображення через плоскопаралельне скло 3 нульовою кривизною) $є$ коло з центром сили у фокусі, однаковим шляхом від центра до периферії у будь-якому напрямку та ідеальністю форми. Такі властивості відомі з античних часів і $є$ основою античної філософії споглядання та цілочисельної філософії Піфагора. Ідеальність означає незмінність форми, яка, як наголосив професор Андрій Содомора, перекладається з латинської не тільки як форма-ємність або форма-ідея, але також як краса. Тільки у цьому разі під час поділу коло не надщерблюється, а породжує таке ж дочірнє коло: цілісне i самодостатнє в кожен момент часу його життя, в чому полягає значення символізму (симболізму) як гармонічних коливань у симбіозі.

\section{2. Механізми утворення еталонів міри в гуманістиці на прикладі}

\section{барокової символіки в емблематичній поезії Теофана Прокоповича}

Природний зв'язок між матір'ю і дитиною $є$ якраз еталоном символізму та симбіозу. Це стосується не тільки матері й дитини, але, як універсальний принцип, фігурує скрізь, де розглядають причиннонаслідкові механізми явищ. Більш загальним є виникнення дочірньої хвилі від материнської, наприклад, розуміння вислову alma mater, у якому закладено механізм утворення дочірньої хвилі через плинність материнського молока. Без розуміння механізму утворення символів виникає безглузде змішування молока матері і навчання в університеті. Як бачимо, в гуманітарних сферах без латинської мови майже неможливо зробити жодного поруху в зовнішньому світі, оскільки за християнською традицією перших університетів мовою побудови 
кожної оберненої перспективи $є$ наукова термінологія, яка і в сучасній гуманістиці латинського і давньогрецького походження. У цьому полягає i значення латинського слова «термін» - границя, межа. В одному разі $з$ трьох ідуть до цієї межі, звужуючи простір вибраної сфери, в іншому - ставлять межу (екран) і після того вивчають співвідношення простору та часу як рефлексію вже відомих символів. Натомість в останньому - розуміючи причинно-наслідкові зв'язки, оперують символікою з різних сфер, яка візуалізується (виховується) на різних етапах розвитку життєвої перспективи найменшого зримого minimum visibile.

У всіх трьох випадках завдання зводиться до перенесення символіки на площину паперу у вигляді мовних або математичних символів. Натомість християнство пропонувало також і візуальні символи. Епоха Відродження розпочалась якраз із упровадження прямої перспективи у мистецтві. Сучасні інформаційні технології передусім пов'язані 3 візуалізацією. Лазерні технології - це також оптичні технології. Україна $\epsilon$ власницею найвизначніших наукових моделей світобудови, пов'язаних із людським зором та ілюзіями. До них належать: український фольклор, творчість Григорія Сковороди і його філософія кордоцентризму, Шевченкові картина i поема «Катерина», збірка «Кобзар». Але з огляду на вищесказане цей поважний перелік нічого не означає без зразків латиномовних українських наукових продуктів, які б засвідчили роль українства у творенні світової терміносистеми. Завдяки клопіткій багаторічній роботі львівських науковців: класичних філологів, філософів, фольклористів, а також мистецтвознавців, медиків та багатьох інших, нам вдалося натрапити на матеріал відповідної вагомості і цінності, який і пропонуємо для розгляду в цій статті. Враховуючи названі особливості кордоцентризму, пропонуємо в дещо іншому світлі розглянути латиномовну поезію Теофана Прокоповича, відштовхуючись від аналізу Мирослава Трофимука та цитованого ним оригіналу в перекладі Володимира Литвинова ${ }^{8}$.

In imaginem B[eati] Virginis Mariae puerum Jesum tenentis

Quid Tyrio matris chlamydem maculare veneno?

Qoid prodest sobolis tingere flore togam?

Hic nec Hipaspalos simules ardere lapillos,

Nec Lybicum, pictor, finge micare jubar.

Pingatur roseis arctari dulcites ulnis

Cum Puero Genetrix, Cum Genetrice Puer.

Murice nobilior, puro pretiosior auro,

Splendidior gemmis unio talis erit.

\footnotetext{
${ }^{8}$ Прокопович Т. Філософські праці. Вибране. Київ : Дніпро, 2012. С. 155, 512.
} 
На образ блаженної Діви Марії з малим Ісусом на руках

Не розфарбовуй хламиду на матері фарбою з Тіру;

Тогу маляті дарма робиш барвистою теж.

І не вдавай, живописию, щяо сяють там перли індійські,

Чи, щзо Лівійське мигтить світло на тім полотні.

Досить того, що зображено їх у взаємних обіймах:

Мати стискає дитя, - ручки й воно простяга.

Образ такий нам цінніший за пурпур і золото щүире;

За самоивіти також він осяйніший для нас'.

За словами дослідника, епіграма «цікава протиставленням топосів царського походження та природного справжнього людського почуття» $^{10}$. Але Теофан Прокопович переслідував мету не тільки «...протиставити пурпурову барву (фарби з Тіру; Тір - Картаген), яка була ознакою володарів у стародавній Греції та Римі...» ${ }^{11}$. Точніше, він не міг цього робити, хоча б тому, що це б порушило гармонію сфер, яка була панівною у філософії тогочасного суспільства. Основною метою могло бути тільки пояснення співмірності, а це охоплює як протиставлення для розрізнення в minimum separabile, так i споріднення - об'єднання під спільними символами з упізнаваністю за найменшою ознакою в minimum cognoscibile. «Тому так органічно вписалась в українську духовну культуру сковородинська філософія серця з ідеєю “сродності” (спорідненості)»" 12 , а ії символом $\epsilon$ пурпурова барва або колір крові, яка споріднює живих людей. I навпаки, символом спорідненості завжди буде кров, кровні зв'язки, кількість крові (крапля, море) як ціна втрати зв'язків, прив'язка до різних сфер-світів: загиблих, рідних, чужих, незвіданих.

«Намалюй, як рожевими ліктями солодко обнялися / Мати із дитятком, з Матір'ю дитятко, / шляхетнішим від пурпуру, ціннішим від чистого золота, дорожчим від перлів буде такий зв'язок» ${ }^{13}$.

Перш за все варто звернути увагу на розмежування двох сфер, яке твориться по колу, починаючи $з$ дитини і закінчуючи також нею. Але важливим $\epsilon$ те, що спочатку дитина $\epsilon$ частиною матері в орудному (в інструментальному) відмінку, а в кінці - ми сприймаємо ії як ціле в називному (в номінативному як номінальному) відмінку через

${ }^{9}$ Прокопович Т. Філософські праці. Вибране. Київ : Дніпро, 2012. С. 155, 512.

${ }_{10}$ Трофимук М. Латиномовна література України XV - IX ст.: жанри, мотиви, ідеї. Львів : ЛНУ ім. Івана Франка, 2014. С. 181.

${ }^{11}$ Там само.

12 Мельник В. Філософія і наука. Антологія сучасної філософії науки, або усмішка ASIMO. Львів : ЛНУ ім. Івана Франка, 2017. С. 16.

13 Трофимук М. Латиномовна література України XV - IX ст.: жанри, мотиви, ідеї. Львів : ЛНУ ім. Івана Франка, 2014. С. 181. 
максимальну розмірність благородності (шляхетності), ціни та вартості в гуманітарному масштабуванні. Cum Puero Genetrix, Cum Genetrice Puer. Завдяки проекції зв'язку на зовнішні критерії максимальних ціннісних співвідношень дві симетричні частини речення отримують однакову цінність символів цілого та частини у їхньому індивідуальному часопросторі. Коло замикається дитиною - центром сфери у називному відмінку, і ми знаємо ії ім'я - Ісус. Так словасимволи іменувань Богородиці переходять в орудний відмінок і стають частиною як точкою відліку усього наступного життя дитини. За іменем Ісуса візуалізується доля людини, відома кожному християнинові в міру індивідуальної освіченості, а отже, кожен буде в дитині бачити власну Боголюдину зі схожістю, яку визнають усі, і 3 відмінністю, що викликана особистими мотивами. Тільки в авторській звізуалізованій формі картини для глядача i слухача назавжди закарбується образ однакового Ісуса, такого, якого символами-словами i символами-фарбами колись зобразили його митці. Дослухаючись до їхніх слів, не зважаючи на відстань у часі, навіть сьогодні, зникає зображення фарб, а залишається зв'язок, який ми відчуваємо реально до власної матері або до власних дітей, звідси і до рідної землі та до рідних дітей цієї землі, зв'язок-союз, якому поставлено ціну: «найважливіше». Так найменше зриме minimum visibile в емблематичній поезії трактуєтся як мірна одиниця в гуманітаристиці аналогічно як одиниця виміру маси (ваги) - однокілограмовий брусок, що зберігається в палаті мір у спеціальних умовах під скляним куполом вважають еталоном у науці. Порівнявши опис еталону маси в сучасній Вікіпедії та епіграму на образ перед очима Теофана Прокоповича, написану близько трьохсот років тому, побачимо, що схеми $\epsilon$ абсолютно ідентичними. У цьому немає нічого дивного, якщо взяти до уваги, що темою в обох випадках $є$ співмірність, або відповідність еталону, та іiі визначення: «Сучасним еталоном кілограма $\epsilon$ циліндрична гиря висотою і діаметром 39 міліметрів, що зберігається в Міжнародному бюро мір і ваг в місті Севрі (передмістя Парижа, Франція. Цю гирю відлито 1879 року зі сплаву платини (90\%) та іридію (10\%), вперше виготовленого французьким хіміком Сент-Клер Девілем 1782 року. Завдяки використанню сплаву платини й іридію збільшилася твердість зразка» ${ }^{14}$.

Найважливішим є дотримання принципу впізнаваності, подібності, схожості у планетарних масштабах простору і вічності в часі, а також повне заперечення принципу розрізнення, що міститься в самому терміні «еталон».

${ }^{14}$ Вікіпедія. URL: https://uk.wikipedia.org/wiki/Кілограм 
Найважливіші ознаки схожості: в обидвох випадках ідеться про зображення, створене людськими руками, яке потрібно побачити, щоб повірити в нього; це символ цілості та неподільності з визначеною найбільшою ціною - «найцінніше» у своїй сфері; ідеться про точку відліку, зокрема про Різдво Ісуса як подію, що визначає координати початку відліку літочислення, аналогічно з еталоном маси звіряють усі міри на землі; мова про зображення глобального планетарного значення; важливі не так внутрішні величини, як їх пропорції; вказують чіткі критерії цінності; важливою є чітка геометрія простору на образі, що символізує союз, або адреса, за умови, що час не має значення в жодному разі; для забезпечення вічності має значення твердість матеріалу і твердість віри, що потребує охорони; кілограм як еталон маси поєднує в собі властивості речовини, яка визначає масу й особливості гравітації землі, що визначає вагу, аналогічно як окреслюють взаємозв'язок матері та дитини через вагітність матері (в українській мові вага і вагітність, як і в латинській мові, мають однакове трактування, на відміну від російської).

Якщо в еталоні маси звертають увагу на твердість, то в еталоні, описаному в епіграмі, ми зустрічаємо саме «солодкість» і «лікті». Коли йдеться про протиставлення, його пов'язують зі символікою ніг, які стоять. Говорячи про лікті, за принципом символізму повинна виникати асоціація «лікоть до ліктя», тобто співдружній, а не опозиційний рух у часі, який до того ж взаємовигідний і взаємодоповнюючий, а отже солодкий. Якщо виникає спогад хоча б про одну сльозу, а тим більше про гірку сльозу, це означає поворот в обернену перспективу, коли в серці існує опозиція, яка жодним іншим способом не проявляється, окрім як сльозою. Українська весільна традиція «засолодити» «гірко!» теж означає підтвердження побудови прямої перспективи супружньої пари, яка до цього моменту не була одним цілим, де руки по мірі сили (ліктя) кожного будують спільне майбутнє сім’ї. Так, силою серця під час кордоцентризму людина може не тільки ділитися і зцілюватися через співвідношення символіки частин, але й множитися через символіку цілочисельних гуманітарних співідношень.

Отож, мова про поезію-емблему «На образ блаженної Діви Марії $з$ малим Ісусом на руках» ${ }^{15}$, де навіть намальовані рожевою фарбою обмеження простору ліктями, $є$ найціннішим зв'язком-союзом на світі. Далі розшифровуються критерії оцінювання такого союзу: критерій розмірності міри поширення - шляхетність (благородність), баланс

${ }^{15}$ Прокопович Т. Філософські праці. Вибране. Київ : Дніпро, 2012. С. 155, 512; Трофимук М. Латиномовна література України XV - IX ст.: жанри, мотиви, ідеї. Львів : ЛНУ ім. Івана Франка, 2014. С. 181-182. 
білого, або точка відліку - чистота, величина фонової яскравості максимальна яскравість. Усі критерії стосуються світла, оптики, зору, точніше хвильових властивостей світла, яке в інерційній системі антропоцентричного виміру означає світло кулястих очей і закони побудови зображення на кулі / у сфері. За критерієм шляхетності, так, наче Murice nobilior, як шляхетний барвник, пурпурова фарба з Тіру, візуальна ознака-символ найшляхетнішого походження володарів у стародавній Греції та Римі; за критерієм чистоти, як Пречиста Діва Марія beata Virgo Maria (образ), щире (чисте) золото puro pretiosior auro; за критерієм яскравості, як найяскравіші самоцвіти splendidior gemmis.

У процесі визначення кожного 3 критеріїв беруть до уваги зображення на площині, яке людина сприймає як світло, яке породжує світло. Символи не мають міри величини, а тільки важливості: вони $€$ дочірніми або материнськими колами, що покликані і самі за законом світла породжувати кола, які можуть бути схожими на материнські, як дочки, або відмінними, як сини. Ісус - син Діви Марії, має свою місію, як i все у світі символів: серце не може бути сердечнішим, шляхетність - шлехетнішою, чистота - чистішою, максимальна яскравість - яскравішою. Тому в оригіналі відсутня вказівка надміру (шляхетніше, ніж шляхетний барвник), але так звучить у перекладі Мирослава Трофимука. У цьому разі він зумисне штовхає нас у колізію «те, що шляхетніше за “найшляхетніше”, тобто за гідність володарів» ${ }^{16}$, коли міра візантійського стилю з його стандартами величин (оберненої перспективи) звучить як гіперметафора «шляхетнішим від пурпуру» ${ }^{17}$, що властиво для прямої перспективи, де ці величини проектуються на читача (означають зусилля, потрачені на подолання відстані до них, у цьому разі за аналогією слова altus, що одночасно означає як глибину, так і висоту, або цінність, у зовнішньому світі прирівнюється до цінності зв'язку матері й дитини на образі). Цього варіанту Володимир Литвинов дотримується з самого початку: «I не вдавай, живописцю, що...», «Досить того, що зображено...», «Образ такий нам цінніший...» ${ }^{18}$. Оскільки перескочити себе самого можна тільки змінивши часопростір, то доцільно просто дотриматися співмірності 3 еталоном, що й робить автор латинського тексту. Але проблемою для українських перекладачів $\epsilon$ те, що еталону офіційно не існує в нашому далекозорому світі науки, тож вони перекладають за універсальною

16 Трофимук М. Латиномовна література України XV - IX ст.: жанри, мотиви, ідеї. Львів : ЛНУ ім. Івана Франка, 2014. С. 181.

${ }_{17}$ Там само.

18 Там само. 
міркою, властивою українцям, - за принципом калокагатії, а отже візуалізуючи у слові для нас усіх еталон самого принципу добропрекрасного.

Саме таке трактування, а не інакше, випливає вже 3 першого речення зі словосполучення maculare veneno, як його пояснив Мирослав Трофимук, а саме у варіанті «плямити любовним напоєм». Цікавим 3 позицій мір ока $\epsilon$ вживання слова «плямити», коли зображення не фокусується на ділянці ока, яка також називається macula lutea - жовта пляма, тоді людина також бачить його розмитим, у вигляді плями. Любовний напій розкриває зміст цілої епіграми як протиставлення магії пурпурової фарби одягу, що, наче любовний напій, дурманить очі, притягує увагу, на відміну від рожевого кольору тіла солодких обіймів ліктів, яким не треба притягувати (ділити), бо вони мусять самі увійти в розуміння (зцілити) шляхом любові (філій і логій). Тому вони, на противагу розмитій плямі розкішного вбрання, $\epsilon$ чітким обмеженням (зображенням) рук - зі значенням об'єднаних кінцівок людських тіл двох поколінь, що призначені власноручно змінювати світ у перспективі. Надзвичайно важливим $є$ розуміння відмінності у математиці цих двох випадків. Розмальовування одягу може бути справді «плямою без меж», тобто чим більше, тим дорожче він виглядатиме. Знак людського тіла вже тільки одною рожевою фарбою позначає цілу людину. Вона не може стати дорожчою чи дешевшою залежно від якості зображення, кількості фарби чи розмірів зображеної руки. Це є співмірність (еметропія) - за принципом найменшого зримого, впізнаваного і розрізнюваного одночасно в точці найменшого зримого minimum visibile, яку навіть не зображено як фокус в оптиці, бо це умовність, кордоцентризм глядача: обійми, союз, «сродність» матері й дитини, людства й Ісуса - те найцінніше, про що й мовиться в епіграмі. Якщо ми визнаємо в зображенні руки (частини) людину (ціле), воно стає найціннішим, якщо ні, або - це не людина, або ми - не люди. Зв'язок, де людина породжує людину навіть в очах, в образі, є найціннішим на землі. Співмірне зображення в очах народжується все і відразу, як при вдало підібраних окулярах, а не будується з частин, складників або точок як перспектива. Епоха бароко, до якої належить поезія Теофана Прокоповича, як жодна інша, запропонувала світові цілочисельні співвідношення в мистецтві та в літературі. Термін «бароко», що перекладається як перлина неправильної форми, сам собою символізує ідеальність форми коласфери-перлини, живого біологічного об'єкта, який в умовах життя на землі набуває неправильної форми, а отже, своєї унікальності і неповторності в конкретному живому просторочасі. 3 таким підходом розглядалась кожна людина в антропоцентричному міркуванні цього 
видатного часу, українським представником якого був Теофан Прокопович, а логічним продовженням стала ідеальність кола кордоцентричної форми світла доброти в людських серцях і красоти в людських очах у філософії Григорія Сковороди - візитівці українського стилю мислення і в наш час.

\section{3. Символіка математики кордоцентризму в українській філологічній спадщині}

На час написання епіграми мірою довжини тканини в Європі були лікті - одиниця міри, що відповідає відстані від ліктя до кінця середнього пальця. Пропорції людського тіла - величина стала, незалежно від відстані при побудові перспективи зображення у просторі або часі, як і образу у вигляді площі на сітківці ока. Так, закони світла та оптики узгоджуються 3 біблійним визначенням антропоцентричного виміру, що око - світильник для тіла, про що стверджувала також забута в наш час цілочисельна сакральна філософія Піфагора, де людина, ії гідність завжди вважається цілою і неподільною: маленька дитина як і ії мати - цілісні люди незалежно від віку. Це пояснює і той факт, що на всіх давнішніх образах Ісус-дитина зображений не за пропорціями дитини, а за пропорціями зменшеного дорослого. Тобто міра в ліктях тканини для одягу на дитину і на маму буде однаковою, якщо міряти, відповідно, їхніми ліктями, такий підхід поширювався абсолютно на всі обчислення. Вимагати від дитини те, що не по її віку (ліктю), є нерозумним, позбавленим логіки, змісту, а також математично безграмотно, а той, хто так рахує, не вважається цілісним, а є частиною своєї примхи вивищуватися навіть над малу дитину: «Нема ні пекла. Ані Раю. / Немає й Бога, тілько я! / Та куций німець вузлуватий, / А більш нікого...» ${ }^{19}$ - так влучно охарактеризував Тарас Шевченко таку близоруку психологію: світ обмежений власними руками, власними страхами, а отже, фіксований до сильнішого, як до матері ще ненароджена людина - залежна, а отже, безвідповідальна у сфері за межами «Я».

Стерео - твердий, грунтовний, фундаментальний, відповідник материнської плати в техніці, металевої матриці з дзеркальним зображенням, від якої утворюють відбитки на папері - в друкарстві. Отже, емблематична поезія Теофана Прокоповича особливо «на образ» є справді емблемою, стереотипним еталоном побудови перспектив перш за все для програмування у свідомості слухача і читача установки на серединний шлях, або пошук «золотої середини» - законів причинно-наслідкових зв'язків, де в людей причиною завжди постає рідна земля і рідна

${ }^{19}$ URL: http://litopys.org.ua/shevchenko/shev140.htm 
мати-першопричина, лоно-параболічне дзеркало материнського колахвилі, що породжує дочірнє коло-хвилю в просторі і часі, або символізм як симбіоз у гуманітарному вимірі живих дзеркал: сітківки ока і людської психіки. «Правдоподібно, що саме цей твір започатковує в українській літературній традиції тему материнства, материнської любові» ${ }^{20}$. Як бачимо, це не тільки започаткування теми, це детальне наукове обгрунтування міри не в одних лише гуманітарних сферах, його можна сміливо прирівняти до фундаментальних фізичних формул, виведених в оберненій перспективі як опис «на образ». Усі сучасні науковці працюють винятково в прямій перспективі, де суб'єктивізм неприпустимий, поширюючи цю ілюзію на гуманітарну сферу.

Тому, дотримуючись переконливої поради поважного автора епіграми, необхідно перестати задивлятися на «одяг» глибоких наукових досліджень у сфері слова і мови, а вникати у зміст, який вони несуть, у животворний блиск світла їхніх всевидящих очей. Принцип Живого Слова через Символ Віри призначений для тих, хто, не маючи освіти, хоч і в темниці, але 3 твердою християнською вірою, а отже, 3 підсвідомим розумінням первинних візуальних символів матері та іiі сина, що з ними зустрічається навіть дитина до того часу, як вивчить символи: букви і цифри. Українське довкілля було найсприятливішим грунтом для таких наукових міркувань. Щедрівка, яка сьогодні полонила світ, що іiі виконують здавна маленькі дівчатка у кожній українській хаті, мало чим відрізняється від наукових трактатів за змістом своєї символіки. Тому порівняння іiі з латиномовною епіграмою авторства видатного українського вченого Теофана Прокоповича буде доречним, щоб зрозуміти важливість містка між об'єктивним і суб'єктивним науковим трактуванням кордоцентризму, настільки майстерно викладеним у цій епіграмі, що зависнувши на одязі, проти чого вже з першого слова застерігає автор, українські перекладачі таки перескакують у світ рідних українських символів добропрекрасного відходячи від ідеї першотвору в розумі, приходять до неї у серці. Це було б неможливим без упливу українського довкілля й особливого менталітету стосовно світу символів: писанки, колядки, щедрівки, вишиванки.

«Подивися на кошару,

Там овечки покотились,

А ягнички народились.

В тебе товар весь хороший,

Будеш мати мірку грочей.

Хоч не гроші, то полова,

В тебе жінка чорноброва» ${ }^{21}$.

${ }^{20}$ Трофимук М. Латиномовна література України XV - IX ст.: жанри, мотиви, ідеї. Львів : ЛНУ ім. Івана Франка, 2014. С. 181.

${ }^{21}$ URL: https://nashe.com.ua/song/4754. 
«Поетична формула стає своєрідною базовою естетичною «клітиною», у згорнутому вигляді якої сконцентровано закономірності життєдіяльності етнокультурного організму загалом» ${ }^{22}$. Співмірність у щедрівці, як і в епіграмі, неможливо пояснити жодним іншим способом, окрім як зрозуміти зв'язок, «подивившись» на кошару, аналогічно, як глянувши на роботу маляра в епіграмі. Якщо овечки не покотяться, то ягнички не народяться, що $є$ аналогом зображення матері й дитини, матері й Ісуса, Діви Марії й малого Ісуса. Але в щедрівці співмірність 3 еталонами цінностей (товар весь хороший) має чіткий вимір в оберненій перспективі, де встановлюється ціна як втрата одиниці виміру, що так і називається: мірка грошей, що проявиться, звізуалізується в майбутньому за потреби обміну (втрати) товару за критерієм «весь хороший».

У щедрівці теж приділено особливу увагу жінці, яка оберігає i виношує дитину, доглядає надбане чоловіком господарство сім'ї, а отже, позначена символом твердості (стихія землі); i, відповідно, полові як стереотипу, від якого утворюються і зернинки-діти, що в цей момент $\epsilon$ перспективою, майбутнім щедрого врожаю за аналогією роду, народу. Символ Ісуса-дитини видозміненено прив'язкою до часу, адже щедрівку виконують у час Різдва, в момент його народження, виконують винятково маленькі дівчатка (символ цілості та непорочності) як майбутні матері, з уст яких, наче ціле мелодійне (не надщерблене) українське «о», звучить програмування такого ж цілого значення багатства в усьому, що позначає зміст, вкладений у слова «щедро», «щедрик», «щедрівка».

$\mathrm{He}$ порушуючи гармонії сфер, філософія кордоцентризму простежується в латиномовній літературі України, зокрема в емблематичній поезії Теофана Прокоповича, де чітко вказано на їі мірні властивості, які жодним іншим способом неможливо передати, окрім як через словесний опис картини (образу), що стає еталоном для утворення стереотипних зображень в уяві людей у будь-яких просторово-часових вимірах 3 єдиним критерієм максимальної важливості в людському суспільстві, аналогічно до сучасного еталону міри маси і ваги. Слово arctari позначає обмеження (не обов'язково обійми) аналогічно до значення слова «термін», що також означає границю. Як бачимо, вже в ті часи було чітко сформульовано закон про зв'язок між двома тілами (між людськими тілами в суб'єктивному вимірі в гуманітарному масштабуванні за аналогією як між фізичними

Гарасим Я. Національна самобутність естетики українського пісенного фольклору. Львів : Львівський національний університет імені Івана Франка, 2010. C. 346 . 
та геометричними тілами в сучасних точних науках в об'єктивному вимірі) та навіть частинами тіл (руками), які зображені на площині символами світла (фарбою кольору тіла), за принципами найменшого зримого в точці найменшого розрізнимого і найменшого впізнаваного, аналогічно як фізичні формули зображені математичними символами, а Декартові осі - перпендикулярними прямими з точкою відліку в місці їх перехрещення. Проте зображення на епіграмі є досконалішим від математичних символів, оскільки одиниця в математиці дорівнює i одиниці в квадраті і в кубі, тоді як на картині автор чітко розмежовує, що союз зображення, яке символізує об'єднання рук, проектується на цінності зовнішнього світу (блиск, шляхетність та чистоту). Саме тому багатство вбрання втрачає значення цінності, як зображення на матері та на дитині, але набуває цінності нульового значення фону, початку відліку, чистоти в системі балансу білого в епіграмі на образ. За подібною логікою вчиняє людина, коли обирає літак, щоб добратися до рідні за критерієм більшої швидкості, який реально забезпечує цей союз як механізм зцілення, а не власні ноги як свою невіддільну частину. Тож вони в цьому разі переводять і саму людину в нульову інерціальну систему відліку, стають лише частиною назви, номінальністю як окрасою, а не інструментом як орудним відмінком у гуманітарному вимірі. Так виникає фон через зміну ваги-важливості 3 нульовою швидкістю, оскільки хода $з$ жодною швидкістю людських ніг у літаку, що летить, не змінює швидкості самого літака. Роботу серця розраховують не 3 позицій роботи, ніг, а з позиції роботи мозкових центрів пілота, що візуалізують переміщення в часопросторі польоту. Аналогічно безглуздо безмірно розмальовувати одяг на образі матері 3 дитиною на руках, як про те писав український філософ, теолог, математик, перекладач, публіцист, науковець-гуманіст, ректор Київської академії Теофан Прокопович ще триста років тому. Бачити те, що справді об'єднує, а не ілюзію з найкращими характеристиками, це $\mathrm{i} \epsilon$ співмірністю, яка стає центром у реальному житті $\mathrm{i}$ забезпечується серцем через математику кордоцентризму. Робота мотора в машині не залежить від напрямку руху, натомість у гуманітарному вимірі навіть одна єдина затаєна людська сльоза на противагу світлу людської усмішки на обличчі свідчить про неспівмірність напряму роботи вірного серця і його волі як руху людини до своєї свободи волевиявлення в конкретному баченні та зображенні просторочасу життя. Таким є механізм кордоцентризму і тлумачення символіки відповідно до анатомії та фізіології людини в антропоцентричній і кардіоцентричній системах відліку. Формульність зображення в епіграмі чітко відповідає тогочасній математиці Франсуа Вієта і Рене Декарта, у якій «про геометричний вплив на концепцію 
величин свідчить спеціальна термінологія: перший степінь величини називається latus (сторона), другий - planum (площина), третій solidum (тіло)» ${ }^{23}$. У такому підході, як бачимо, закладено міри ока. Натомість в епіграмі ми бачимо ті ж степені у символах одягу, зв'язку матері та дитини, яку вона виношувала і народила: шляхетність у візуалізації червоної фарби (плинність або площинний вимір), чистоту в металі (тілесний вимір, солідарність, вимір твердої стихії, землі, стереотипу, точки відштовху і відліку), і максимальність яскравості у блиску (вимір сторони, коли параметр або є, або відсутній).

\section{ВИСНОВКИ}

Наведений зразок барокової емблематичної поезії $є$ унікальним свідченням глибокого наукового підходу до розуміння кордоцентризму в латиномовній поезії України в часи Теофана Прокоповича, яке навіть на сучасному рівні розвитку науки $\mathrm{i}$ техніки $\epsilon$ основним $\mathrm{y}$ гуманітарному вимірі. Тому ця знахідка може стати еталоном важливим внеском у фундаментальні терміносистеми світового значення поряд із Вітрувіанською людиною. Тільки подібні латиномовні твори виводять уявлення про українську філософію кордоцентризму на якісно інший рівень, а саме на рівень фундаментальних законів у гуманітарному вимірі. «Спільне добро твоїм по праву стане як тільки / Вирвешся 3 кола, що всяк у нім крутиться, і перестанеш / Слово в слово товкти, як товмач, безоглядно вірний...» ${ }^{24}$. Ці слова великого Горація, на якого завжди опиралися Теофан Прокопович та Григорій Сковорода, пояснюють, як через слово, що завжди було спочатку, людина долає межі твірного кола буття. Очевидно, що час перлини неправильної форми в системах доповнених та віртуальних реальностей сучасних IT сфер органічно переходить в іншу ідеальну форму сфери в гуманітарному вимірі. Ïї задовго до ери інформаційних технологій наш український академік Вернадський назвав ноосферою. Тож цілком закономірно, що проект НООСФЕРА започаткований професором-фольклористом Ярославом Гарасимом у Львівському національному університеті імені Івана Франка у 2017 році був присвячений 80-річчю перекладача Горація, професора Андрія Содомори. Так дослідження світової та вітчизняної латиномовної спадщини роблять Україну сучасним центром гуманістики з центруванням у реальних живих людських серцях на

\footnotetext{
${ }^{23}$ Математична хрестоматія. Алгебра і початки аналізу / за ред. М.І. Кованцова. Київ : Радянська школа, 1977. С. 18.

${ }^{24}$ Содомора А. Студії одного вірша. Львів : Видавничий центр ЛНУ імені Івана Франка, 2006. С. 9.
} 
засадах філософії кордоцентризму Григорія Сковороди - визнаної світом візитівки традиційного українського стилю мислення.

\section{АНОТАЦІЯ}

Подано результати дослідження латиномовної спадщини України. Запропоновано визнати емблематичну поезію під назвами « In imaginem...» («На зображення...») еталоном міри у філософії серця Григорія Сковороди. За основу взято епіграму на релігійну тему, що $\epsilon$ також і зразком емблематичної поезії. Аргументація опирається на дослідження праць львівського неолатиніста Мирослава Трофимука: цитованого ним оригіналу поезії Теофана Прокоповича "In imaginem B[eati] Virginis Mariae puerum Jesum tenentis", а також у перекладі Володимира Литвинова. Візуальні символи розглянуто за схемою утворення зображення в сфері, що відповідає антропоцентричній системі гуманітарних вимірів. У мистецтві ці схеми відомі як побудова прямої і оберненої перспективи, створеної уявою і рукою митця по відношенню до ока глядача. У наш час такий підхід в літературі широко застосовується українськими перекладачами. Перекладні й авторські твори львівського професора Андрія Содомори розкривають для філологів методологію мір ока, базовану на математиці.

Так, дослідження латиномовної спадщини позиціонують Україну сучасним центром гуманістики 3 центруванням у реальних живих людських серцях на засадах філософії кордоцентризму Григорія Сковороди - визнаної світом візитівки традиційного українського стилю мислення.

\section{ЛIТЕРАТУРА}

1. Гарасим Я. Національна самобутність естетики українського пісенного фольклору. Львів : Львівський національний університет імені Івана Франка, 2010. С. 287, 346.

2. Математична хрестоматія. Алгебра і початки аналізу / за ред. М. І. Кованцова. Київ : Радянська школа, 1977. С. 18.

3. Мельник В. Філософія і наука. Антологія сучасної філософії науки, або усмішка ASIMO. Львів : ЛНУ ім. Івана Франка, 2017. C. 15,16 .

4. Прокопович Т. Філософські праці. Вибране. Київ : Дніпро, 2012. C. 155,512 .

5. Содомора А. Студії одного вірша. Львів : Видавничий центр ЛНУ імені Івана Франка, 2006. С. 9.

6. Трофимук М. Латиномовна література України XV-IX ст.: жанри, мотиви, ідеї. Львів : ЛНУ ім. Івана Франка, 2014. С. 176, 180-182. 
7. Вікіпедія. Кілограм. URL: https://uk.wikipedia.org/wiki/Кілограм.

8. Шевченко T. I мертвим, і живим, і ненародженим землякам моїм в Україні і не в Україні моє дружнєє посланіє. Шевченко Т. Зібрання творів : у 6 т. Т. 1 : Поезія 1837-1847. Київ, 2003. С. 348-354; C. 737-740. URL: http://litopys.org.ua/shevchenko/shev140.htm.

9. Щедрик, щедрик, щедрівочка // НАШЕ (тексти пісень). URL: https://nashe.com.ua/song/4754/

\section{Information about the author:}

Sverediuk U. D., Applicant at the Department of Folklore Studies named after Academician Filaret Kolessa Ivan Franko National University of Lviv 1, Universytetska str., Lviv, 79000, Ukraine 